\title{
The Birth of a Dragon Fly
}

\section{By COLIN G. DOWSLEY}

About five years ago, when age had caught up with me, I retired from a Canadian bank and took root in the delightful village of Athens, in the interior of Leeds county, Ontario, which borders the St. Lawrence river.

Five miles from Athens is Charleston Lake, in my view the prettiest Lake in this part of Canada. It contains 144 islands, on one of which I have a small cottage. I live there from May until October, and spend a good deal of time communing with and studying Nature.

By providing some inducements I have coaxed to my little island kingdom (less than half an acre) a number of useful birds, 87 pairs of purple martins, 15 pairs of tree swallows, a barn swallow, a kingbird, a phoebe, a robin, a chipping sparrow, a song sparrow, a Baltimore oriole, and though unwanted, a starling.

Then, too, I have some fish. For years past, a four-pound black bass has inhabited the lagoon each spring and for several weeks after the hatching, the male rides herd on his many thousand progeny as they course in a leisurely manner just beneath the surface.

Near the kitchen door I have about 30 sunfish, always hungry. They are smart little fellows and should make good ball-players, for when I throw food out into deep right or left fields, the whole group will quickly turn and speed in that direction before the food has yet touched the water.

I made friends last summer with a little bass, about three inches long, that selected a parking place under the motorboat at the dock. He was always there, and not at all timid, for, when I would put my finger in the water near him, he would nibble it.

The highlight of my years at the lake, however, occurred last summer and was the most amazing transformation I have ever seen - the birth of a dragon fly.
I had known that a dragon fly emerges from a nymph, which, until the proper moment, spends its entire life under water, usually buried in the sand or mud, excepting its eyes which protrude like periscopes. These nymphs, when ready, which is usually at night, crawl out of the water and climb rushes, nearby trees, or the sides of buildings only a short time before the transformation is to take place, and fasten themselves there as their final act.

When out near the woodshed one day I noticed on the cement walk near the water a nymph that was still wet, so I picked it up and took it to the veranda where I put it in a glass tumbler together with a thin chip of wood. In a couple of minutes it climbed up on the chip and dried out.

Then, as I watched, I saw a lump form at the back of the neck and shoulders, and in about a minute two large greenish balls came through a rift in the nymph's hide. These were the head, or rather, the 10,000 multiple eyes of the dragon fly.

As I watched, the head came completely through, moving and twisting. In about five minutes more the shoulders emerged, and wriggled about, followed in another five minutes by half of the torso. Each of the forelegs then appeared in turn and stretched itself full length.

The fly was building itself sideways the while, and what had now emerged was almost the size of the original nymph. In another five minutes, the second pair of legs made their appearance. Then in a few minutes more came the hind legs, by a process of pulling, hoisting and wriggling, like a small boy extricating himself from tight-fitting combination underwear.

When all six legs were free, the fly leaned backwards from the perpendicular and rested for about five minutes, without much further bodily movement, but enlarging itself in all directions, while the head and body progressively changed colors. 
I noticed the absence of wings and could see only four curved yellow marks where they should be. As I watched, these yellow marks built themselves outward, fairly solidly, but thinning out as they grew. In a very few minutes they were about half an inch long and were becoming thinner and transparent. In another few minutes the gossamer wings were forming with a multitude of veins or ribs; they were an inch or more long and nearly complete.

Then that part of the dragon fly which had by now emerged, and which was much bigger than the nymph ever was, lurched forward, seized the chip above the nymph's head, and astonished me by commencing to pull out the tail, little by little, and then to drag it straight out behind. It was transparent like a glass tube, had parallel sides, and you could see the alimentary canal throughout its length.

As I watched, the tail lengthened, became thinner and commenced to change to a darker color, after which it built a bulbous end on itself. Gradually the whole tail turned brown, then black, and developed lateral yellow rings.

By now this marvellous insect was nearly complete and no further large change took place. It rested and fluttered its wings from time to time as though testing them out, and then further decorated itself with new colors.

In a little while it flew out of the tumbler and got on the wire screen and flew spasmodically a few inches at a time. The eyes, which at first were light green, were now blackish from constant wiping with the forelegs. It began to fly greater distances and then took a long flight of 10 or 12 yards.

By now it was a fine-looking, powerful fellow, and as it had not yet had any breakfast I felt it was ready for the war on mosquitoes, so I opened the screen door and let it go.

It flew into a cedar tree about 10 yards away, and I have not seen it since. It might at least have bade me "good-bye" and come back once in a while to say "Hello".

\section{Patterns of Joy: Jubilee Year, 1955}

\section{By ELIZABETH CRUICKSHANK}

"Sound the Jubilee trumpets" said the swallows: barn, bank, cliff and tree swallows as they arrived on a cold gale-filled day in mid-May. Some of the sturdier continued to fly low in graceful rhythm but hundreds of them settled wearily on the rich brown earth or the dark green grass, an iridescent moving mosaic of steely blue-black, pure white, brown and chestnut.

So had come the companies of white-throats, white-crowned, the juncos and the thrushes, the myrtles, the yellow-heads in crowds, as if on special invitation to help Saskatchewan people celebrate.

We had always seen single thrashers. To our surprise one day we saw a whole family tumble from a nest and hurry through the grass.

To have never seen a dowitcher then have eight land on a slough before us, then ten, then twenty! Could we ring the bells this year 1955! Avocets phalaropes, rails, phoebes (Say's), towhees, blue-birds, sandpipers, all have made this year memorable.

And the dragonflies, were there ever such crowds of them! One we though a bird as it plummetted down to swim in the creek, its gossamer wings glistening like beaten copper in the sunlight.

Of all the colourful parades this year none could surpass the coneflowers' gay displays, their lavish golden banners flying, their brown standards straight and tall. And no parade could have been more orderly than a ribbon of black ants we followed as they marched up and down and round about the sandy hills in search of a new home.

Not all our golden experience had to do with crowds, however.

There has been an altered look about the land this year - so much water on the prairie and in the valleys; such lush growth; such haunting fragrance from sweet clover and thistle vieing with each other;

(Continued on page 36 ) 